\title{
Assay of gastricsin and individual pepsins in human gastric juice
}

\author{
A T Jones, K K Balan, S A Jenkins, R Sutton, M Critchley, N B Roberts
}

\begin{abstract}
Aims: To develop and validate an analytical procedure for the quantitation of pepsins and gastricsin in human gastric juice and to assess its potential in a controlled gastric secretory study.

Methods: High performance ionexchange chromatography was used to separate human pepsin $1,3 a, 3 b, 3 c$ and gastricsin from gastric juice. Computed chromatographic areas for each enzyme were quantified by relation to a known amount of a secondary standard porcine pepsin. The assay procedure was validated by recovery and analytical precision studies. Gastric secretions after pentagastrin and insulin stimulation from 10 patients with portal hypertension were used to assess the potential of the analytical procedure.
\end{abstract}

Results: The assay precision varied from 1.5 to $9.0 \%$ within batch and 7.5 to $18 \cdot 1 \%$ between batch, with about $100 \%$ recoveries of porcine pepsin $A$ from human gastric juice over the assay range $0.025-0.5 \mathrm{mg} / \mathrm{ml}$. A fourfold increase in combined pepsin and gastricsin concentration was observed following pentagastrin and insulin stimulation. The mean percentage content of pepsins $3 a, 3 b, 3 c$, and 1 in non-stimulated gastric juice were $4 \%, 72 \%, 12 \%$ and $1.4 \%$, respectively, and did not change significantly after gastric stimulation. An approximate doubling of the percentage of gastricsin $(10 \%$ to $20 \%)$ relative to the pepsins was observed, however, after both insulin and pentagastrin stimulation.

Conclusions: This procedure for quantifying individual human pepsins and gastricsin in gastric juice is simple and reliable. It may be of considerable importance in determining the mechanisms involved in the control and secretion of these digestive enzymes in man, including the effect of anti-ulcer drugs and our understanding of the pathophysiology of peptic ulcer disease.

(F Clin Pathol 1993;46:254-258)

There is a paucity of simple and reliable assays suitable for the quantitation of individual human pepsins in gastric juice, and in particular human pepsin 1 (nomenclature of Etherington and Taylor). ${ }^{1}$ Pepsin 1 was increased in patients with peptic ulcer disease $^{2}$ and subsequently shown to have high mucolytic and collagenolytic properties. ${ }^{3}$ It would be of considerable interest to know the different pepsin secretion profiles in gastric juice because several studies have reported that an increased total pepsin secretion has an important role in the pathogenesis and reduced healing rates in peptic ulceration. ${ }^{4}$

The most reported analytical procedures for gastric juice pepsin quantitation have used the measurement of "total" enzymic activity against various protein substrates, such as bovine haemoglobin. ${ }^{5}$ Unfortunately, these assays do not allow for the different proteolytic specificities ${ }^{6}$ and $\mathrm{pH}$ optima ${ }^{7}$ of pepsin $\mathrm{A}$ and pepsin C (gastricsin). ${ }^{8}$ Selective measurement of pepsins has been attempted using the di-peptide substrate $\mathrm{N}$-acetyl-Lphenylalanyl-diiodotyrosine and by inhibition with pepstatin. ${ }^{9}$ Axelsson et $a l^{10}$ reported the quantitation of human pepsin A (a mixture of pepsin $3 a, b$ and $c$ but not 1 ) and gastricsin in gastric juice using rocket immunoelectrophoresis. Separation of the pepsins by agar gel electrophoresis and semiquantitation based on the visualisation of areas of proteolysis by negative Ponceau S staining ${ }^{11}$ or elution of each enzyme zone followed by succinyl albumin proteolysis has also been developed. ${ }^{12}$ Unfortunately these procedures cannot quantify pepsin $\mathrm{A}$ isoenzymes individually, are time consuming, and analytically imprecise.

We describe a simple quantitative assay for the four human pepsin $\mathrm{A}$ isoenzymes and gastricsin in human gastric juice based on the previously established separation procedure with high performance ion-exchange chromatography (HPIEC). ${ }^{13}$

\section{Methods}

AnalaR sodium hydroxide, anhydrous sodium acetate, glacial acetic acid and dialysis tubing ID 14.3 and $25.4 \mathrm{~mm}$ was obtained from British Drug Houses (Poole, Dorset) and porcine pepsin A from Sigma (Poole, Dorset).

The instrumentation comprised an SM 3000 ultraviolet light detector, CM 4000 low pressure tertiary mixing pump, manually operated Rheodyne valve $(250 \mu \mathrm{l})$ loop, and CI 4000 computing integrator (LDC, Stone England), TSK DEAE 5 PW $7.5 \times 0.75 \mathrm{~cm}$ ID anion exchange column (Anachem Ltd. Luton, Beds) with guard column containing DEAE-5PW TSK guardgel. Radiometer PHM 62 Standard pH meter (Radiometer, Copenhagen, Denmark) 
Gastric juice $2-250 \mathrm{ml}$ was initially filtered through $113 \mathrm{~V} 320 \mathrm{~mm}$ diameter (Whatman LabSales Ltd. Maidstone England) filter paper to remove mucoid and particulate material. The filtrate was dialysed for 24 hours against $2 \times 5$ litre volumes of $50 \mathrm{mM} / 1$ sodium acetate buffer $(\mathrm{pH} 4 \cdot 1)$ at $4^{\circ} \mathrm{C}$, filtered through Whatman $43110 \mathrm{~mm}$ diameter filter paper, and either stored at $-20^{\circ} \mathrm{C}$ for up to 16 hours or injected immediately on to the HPIEC system. To avoid pepsin autolysis samples were always maintained at $4^{\circ} \mathrm{C}$ (icewater) before each manual injection.

Gastric dialysate $(150 \mathrm{nl})$ or standard porcine pepsin A solutions were manually injected on to the chromatography system and the pepsins eluted using the linear gradient from 0-9\% B over 1 minute, 9-15\% B over 11 minutes, $15 \%$ B for 6 minutes, $15-70 \%$ B over $0 \cdot 1$ minute, $70-80 \%$ B generated over 4.8 minutes (total time $22.9 \mathrm{~min}$ utes). Solvent $A$ is $50 \mathrm{mM} / 1$ sodium acetate buffer ( $\mathrm{pH} 4 \cdot 1$ ) and solvent $\mathrm{B}$ is solvent $\mathrm{A}$ containing $1 \mathrm{M} / 1 \mathrm{NaCl}$. Flow was rate $1 \cdot 1$ $\mathrm{ml} /$ minute and the operating back pressure was 200 pounds per square inch. To optimise chromatographic separation and ensure analytical reproducibility a stored $\left(-20^{\circ} \mathrm{C}\right)$ "control" sample of gastric juice was analysed before each batch of patient samples. Chromatographic problems were usually solved by replacement of blocked on-line filters or renewal of guardgel, or both. The individual chromatographic peak areas were recorded and converted to corresponding porcine pepsin A concentration equivalents by comparison with a calibration curve 0-500 $\mu \mathrm{g} / \mathrm{ml}$ porcine pepsin $\mathrm{A}$ in $50 \mathrm{mM} / 1$ sodium acetate buffer ( $\mathrm{pH} 4 \cdot 1$ ). Porcine pepsin A eluted at the same time as human pepsin 1 using the gradient in fig 1 and was resolved into two peaks (one major $80 \%$ and one minor $20 \%$ ), the areas of which were added to give a total peak area for calibration studies. Gastric juice samples with pepsin concentrations of $>500 \mu \mathrm{g} / \mathrm{ml}$ were diluted 1 in 1 with $50 \mathrm{mM} / 1$ sodium acetate buffer before chromatography again.

Within-batch variation expressed as mean \pm standard deviation of the mean (SD) for four human pepsins and gastricsin was calculated after 10 consecutive injections of $150 \mu \mathrm{l}$ processed gastric juice, and between-batch variation established over seven weeks after injecting $150 \mu \mathrm{l}$ aliquots $(\mathrm{n}=19)$ of gastric juice stored at $-20^{\circ} \mathrm{C}$.

A sample of gastric juice was divided into six $25 \mathrm{ml}$ aliquots and each spiked with porcine pepsin to give final concentrations of $25,50,125,250$, and $500 \mu \mathrm{g} / \mathrm{ml}$ with an unspiked aliquot as a control sample. The gastric juice samples were then processed and peak areas for duplicate injections of spiked samples compared with untreated porcine pepsin solutions of equivalent concentrations injected directly on the HPIEC system. This permitted both an assessment of recovery and reproducibility of the standardisation procedure.

Gastric juice samples were obtained from



Figure 1 Ion exchange chromatography of four human pepsins 1, 3a, 3b, 3c and gastricsin (G) from $150 \mu l$ gastric dialysate. The slight negative "dip" in the baseline at 22 minutes was due to the change in solvent absorption at $280 \mathrm{~nm}$.

10 (eight men, two women; mean ages 51 and 45 years, respectively) portal hypertensive patients with obliterated oesophageal varices and portal hypertensive gastropathy undergoing a standard pentagastrin $(6 \mu \mathrm{g} / \mathrm{kg}$ intramusially) and insulin ( 0.2 units $/ \mathrm{kg}$ intravenously) gastric secretion test. ${ }^{14}$ Continuous aspirations of gastric juice were collected during the following time periods: basal (30 minutes), pentagastrin (up to 60 minutes after pentagastrin administration), insulin control (30 minutes before insulin) and after insulin (for 30-75 minutes after insulin injection). Blood glucose was monitored at 15 minute intervals after insulin injection to ensure an adequate hypoglycaemic challenge-a blood sugar of less than $2.0 \mathrm{mmol} / 1$. The patients were instructed as to the nature of the procedures and their written informed consent obtained. The study was authorised by the hospital's ethical committee.

Before initial filtration gastric juice volume and $\mathrm{pH}$ were measured and $1 \mathrm{ml}$ aliquots were titrated against $50 \mathrm{mM} / 1 \mathrm{NaOH}$ for calculation of hydrogen ion concentration. Gastric juices were then processed the same day according to the method described. Each batch of patient samples was analysed on the same day to minimise analytical error.

The statistical difference of the different distributions in the various groups was determined by means of Student's $t$ test and the analysis of variance (ANOVA).

\section{Results}

A typical profile of human pepsin isoenzymes in gastric juice after ion-exchange chromatography is shown in fig 1 , showing the separation of the pepsin isoenzymes $3 a, b, c, 1$ and gastricsin. The relative retention times were used to classify each isoenzyme in the separate gastric juices, and did not vary by more than 0.1 minutes within each daily batch analysis -16 injections. 
Figure 2 Calibration curves for porcine pepsin $A$ by ion-exchange chromatography.

$\triangle$ porcine pepsin $A$ in 50 $\mathrm{mM} / \mathrm{l}$ sodium acetate buffer; $\star$ porcine pepsin $A$ in gastric juice (corrected peak areas were plotted after subtraction of the coeluting pepsin 1 from porcine pepsin).



Table 1 Precision data for human pepsin isoenzyme quantitation from gastric juice using ion-exchange chromatography

\begin{tabular}{|c|c|c|c|c|c|c|}
\hline \multirow[b]{2}{*}{ Gastricsin } & \multicolumn{3}{|c|}{ Within-batch $n=15$} & \multicolumn{3}{|c|}{ Between-batch $n=19$} \\
\hline & $\begin{array}{l}\text { Mean } \\
(m g / m l)\end{array}$ & $S D$ & $C V \%$ & $\begin{array}{l}\text { Mean } \\
(\mathrm{mg} / \mathrm{ml})\end{array}$ & $S D$ & $\mathrm{CV} \%$ \\
\hline $\begin{array}{l}5 \\
3 \mathrm{c} \\
3 \mathrm{~b} \\
3 \mathrm{a} \\
1\end{array}$ & $\begin{array}{l}0.046 \\
0.020 \\
0.285 \\
0.013 \\
0.003\end{array}$ & $\begin{array}{l}1 \cdot 07 \\
0.08 \\
4 \cdot 18 \\
0 \cdot 14 \\
0 \cdot 0001\end{array}$ & $\begin{array}{l}9 \cdot 0 \\
1.5 \\
5.7 \\
4.5 \\
13 \cdot 1\end{array}$ & $\begin{array}{l}0.037 \\
0.018 \\
0.311 \\
0.110 \\
0.007\end{array}$ & $\begin{array}{l}0.99 \\
0.50 \\
5.34 \\
0.46 \\
0.0004\end{array}$ & $\begin{array}{r}11 \cdot 5 \\
12.3 \\
7 \cdot 5 \\
18 \cdot 0 \\
26 \cdot 2\end{array}$ \\
\hline
\end{tabular}

Separate calibration curves of spiked processed gastric juice samples and standard porcine pepsin solutions gave identical slopes (fig 2) with percentage porcine pepsin A recoveries from gastric juice of $95 \%, 98 \%$, $101 \%, 93 \%$ and $100 \%$ for additions to 500 , $250,125,50$, and $25 \mu \mathrm{g} / \mathrm{ml}$ (final concentrations), respectively; no significant matrix effect on porcine pepsin recovery was thus observed. It was therefore possible to use a spiked gastric juice or a porcine pepsin A solution for calibration purposes.

The precision of the assay for pepsin isoenzymes $3 \mathrm{a}, \mathrm{b}, \mathrm{c}$, and gastricsin varied from 1.5 to $9.0 \%$ within-batch and 7.5 to $18.1 \%$ between-batch (table 1). The overall poor between-batch precision for pepsin 1 compared with the other pepsins was due to its low concentration in the gastric juice tested$<0.02 \mathrm{mg} / \mathrm{ml}$-which approached the detection limits of the assay described in this study.

Gastric juice pepsin profiles from the 10 patients studied are shown in table 2 . Of the 10 basal samples, four were unsuitable for pepsin analysis due either to bile reflux which resulted in a high gastric juice $(\mathrm{pH}>3.5)$, or

Table 2 Profiles of volume, $p H$, and gastricsin and pepsin concentrations calculated using ion-exchange chromatography from gastric juice of patients before and after gastric stimulation with pentagastrin and insulin

\begin{tabular}{|c|c|c|c|c|}
\hline & Basal & $\begin{array}{l}\text { After } \\
\text { pentagastrin }\end{array}$ & $\begin{array}{l}\text { Insulin } \\
\text { control }\end{array}$ & $\begin{array}{l}\text { After } \\
\text { insulin }\end{array}$ \\
\hline $\begin{array}{l}\text { No of patients } \\
\text { Mean (SEM) pH } \\
\text { Median } \\
\text { Range } \\
\text { H + mmol// } \\
\text { Mean (SEM) } \\
\text { Median } \\
\text { Range } \\
\text { Mean (SEM) Vol ml } \\
\text { Median } \\
\text { Range } \\
\text { Gastricsin mg/ml } \\
\text { Mean (SEM) } \\
\text { Median } \\
\text { Range } \\
\text { Gastricsin mg/sample } \\
\text { Mean (SEM) } \\
\text { Median } \\
\text { Range } \\
\text { Pepsin } 3 \mathrm{mg} / \mathrm{ml} \\
\text { Mean (SEM) } \\
\text { Median } \\
\text { Range } \\
\text { Pepsin } 3 \mathrm{mg} / \mathrm{sample} \\
\text { Mean (SEM) } \\
\text { Median } \\
\text { Range }\end{array}$ & $\begin{array}{l}6 \\
1.47(0.21) \\
1.42 \\
0.64-2.06 \\
69(16) \\
88 \\
18-103 \\
52(14) \\
40 \\
20-105 \\
0.031(0.013) \\
0.024 \\
<0.01-0.09 \\
2 \cdot 2(1 \cdot 37) \\
1.2 \\
0.02-8.9 \\
0.269(0.079) \\
0.192 \\
0.09-0.59 \\
13.3(4 \cdot 2) \\
11.1 \\
1.9-26.7\end{array}$ & $\begin{array}{l}10 \\
1 \cdot 13(0 \cdot 07) \\
1 \cdot 18 \\
0 \cdot 52-1 \cdot 27 \\
95(11) \\
98 \\
19-133 \\
130(26) \\
112 \\
25-250 \\
0 \cdot 087^{\star}(0 \cdot 016) \\
0 \cdot 075 \\
0 \cdot 04-0 \cdot 17 \\
13 \cdot 0(4 \cdot 11) \\
7 \cdot 9 \\
1 \cdot 1-35 \cdot 7 \\
0 \cdot 360^{\star}(0 \cdot 029) \\
0 \cdot 322 \\
0 \cdot 28-0 \cdot 53 \\
48 \cdot 8(11 \cdot 9) \\
36 \cdot 8 \\
7 \cdot 8-130 \cdot 8\end{array}$ & $\begin{array}{l}10 \\
1 \cdot 18(0.09) \\
1 \cdot 21 \\
1 \cdot 10-1 \cdot 40 \\
88(12) \\
88 \\
40-138 \\
49(12) \\
32 \\
5-110 \\
0.080^{\star}(0.016) \\
0 \cdot 087 \\
<0 \cdot 01-0 \cdot 18 \\
3.3(1.0) \\
2.9 \\
0.08-11 \cdot 0 \\
0 \cdot 299(0.050) \\
0 \cdot 262 \\
0 \cdot 10-0.66 \\
13.8(3.8) \\
9 \cdot 4 \\
2 \cdot 1-31 \cdot 7\end{array}$ & $\begin{array}{l}10 \\
1 \cdot 10(0 \cdot 08) \\
1 \cdot 09 \\
0 \cdot 53-1 \cdot 45 \\
\\
98(11) \\
99 \\
31-147 \\
56(11) \\
42 \\
20-110 \\
0 \cdot 159^{\star \star}(0.021) \\
0 \cdot 133 \\
0 \cdot 10-0 \cdot 28 \\
9 \cdot 2(2 \cdot 5) \\
7 \cdot 6 \\
2 \cdot 3-28 \cdot 6 \\
0 \cdot 604^{\star \star}(0.069) \\
0 \cdot 560 \\
0 \cdot 36-1 \cdot 06 \\
35 \cdot 5(8 \cdot 6) \\
23.6 \\
8 \cdot 9-82 \cdot 0\end{array}$ \\
\hline
\end{tabular}

Pepsin $3=3 a, b$, c, and 1 combined.

No significant difference compared with basal unless indicated:

No significant difference

Collection volumes and enzyme output per samples were not compared because of differences in collection times.

Table 3 Percentage content of human pepsins and gastricsin in gastric juice of patients before and after gastric stimulation with pentagastrin and insulin

\begin{tabular}{|c|c|c|c|c|c|c|}
\hline \multirow[b]{2}{*}{ Sample } & \multirow{2}{*}{$\begin{array}{l}\text { No of } \\
\text { patients }\end{array}$} & \multicolumn{5}{|c|}{ Percentage of total area of each pepsin isoenzyme } \\
\hline & & Gastricsin & Pepsin $3 c$ & Pepsin $3 b$ & Pepsin $3 a$ & Pepsin 1 \\
\hline Basal & 6 & $\begin{array}{l}10 \cdot 9(3 \cdot 8) \\
7 \cdot 3 \\
1 \cdot 3-26 \cdot 8\end{array}$ & $\begin{array}{l}12 \cdot 2 \pm 5 \cdot 7 \\
8 \cdot 7 \\
3 \cdot 0-40\end{array}$ & $\begin{array}{l}71 \cdot 5 \pm 7 \cdot 2 \\
79 \cdot 9 \\
46 \cdot 6-87 \cdot 3\end{array}$ & $\begin{array}{l}4 \cdot 0 \pm 1 \cdot 0 \\
4 \cdot 2 \\
0-7 \cdot 1\end{array}$ & $\begin{array}{l}1 \cdot 4 \pm 1 \cdot 1 \\
0 \cdot 2 \\
0-7 \cdot 1\end{array}$ \\
\hline After pentagastrin & 10 & $\begin{array}{l}19 \cdot 2(3 \cdot 0) \\
15 \cdot 8 \\
5 \cdot 4-33.8\end{array}$ & $\begin{array}{l}7.9 \pm 3 \cdot 3 \\
5 \cdot 2 \\
2 \cdot 4-37 \cdot 0\end{array}$ & $\begin{array}{l}65 \cdot 6 \pm 4 \cdot 0 \\
62 \cdot 9 \\
49 \cdot 0-81 \cdot 4\end{array}$ & $\begin{array}{l}4.3 \pm 0.9 \\
4 \cdot 0 \\
0-10 \cdot 9\end{array}$ & $\begin{array}{l}3.0 \pm 0.9 \\
2 \cdot 7 \\
0-8.0\end{array}$ \\
\hline Insulin control & 10 & $\begin{array}{l}20 \cdot 0 \pm 3 \cdot 3 \\
19 \cdot 6 \\
1 \cdot 4-32 \cdot 4\end{array}$ & $\begin{array}{l}8.5 \pm 3 \cdot 6 \\
4 \cdot 7 \\
3 \cdot 3-40 \cdot 9\end{array}$ & $\begin{array}{l}63.8 \pm 3.5 \\
59 \cdot 6 \\
46 \cdot 6-82.0\end{array}$ & $\begin{array}{l}3.7 \pm 1.3 \\
3.8 \\
0-9.6\end{array}$ & $\begin{array}{l}4 \cdot 0 \pm 0 \cdot 8 \\
1 \cdot 4 \\
0-13 \cdot 2\end{array}$ \\
\hline After insulin & 10 & $\begin{array}{l}21 \cdot 0^{\star} \pm 1 \cdot 6 \\
21 \cdot 0 \\
11 \cdot 5-30 \cdot 2\end{array}$ & $\begin{array}{l}7 \cdot 8 \pm 2 \cdot 8 \\
4 \cdot 2 \\
2 \cdot 5-32 \cdot 4\end{array}$ & $\begin{array}{l}64 \cdot 3 \pm 3 \cdot 5 \\
67 \cdot 5 \\
48 \cdot 3-77 \cdot 7\end{array}$ & $\begin{array}{l}4 \cdot 0 \pm 1 \cdot 3 \\
4 \cdot 0 \\
0-8 \cdot 4\end{array}$ & $\begin{array}{l}2 \cdot 9 \pm 1 \cdot 0 \\
1 \cdot 7 \\
0-11 \cdot 0\end{array}$ \\
\hline
\end{tabular}

Results reported as percentage mean (SEM) median and range.

* Significant compared with basal $p<0.05$.

Individual enzyme content are expressed as a percentage of the total enzyme area calculated after HPIEC. 
Table 4 Human pepsins and gastricsin percentage content in gastric juice of two patients with increased pepsin $3 c$ (a) and gastricsin (b)

\begin{tabular}{|c|c|c|c|c|c|}
\hline \multirow[b]{2}{*}{ Sample } & \multirow[b]{2}{*}{ Gastricsin } & \multicolumn{4}{|c|}{$\%$ of total area } \\
\hline & & $3 c$ & $3 b$ & $3 a$ & 1 \\
\hline $\begin{array}{l}\text { Basal } \\
\text { After pentagastrin } \\
\text { Insulin control } \\
\text { After insulin } \\
\text { Patient: female } 25\end{array}$ & $\begin{array}{c}12 \cdot 6 \\
12 \cdot 2 \\
1 \cdot 4 \\
21 \cdot 1 \\
\text { lcoholic cir }\end{array}$ & $\begin{array}{r}40 \cdot 0 \\
37 \cdot 0 \\
40 \cdot 9 \\
32 \cdot 4 \\
\text { sis, ga }\end{array}$ & $\begin{array}{l}47 \cdot 4 \\
49 \cdot 0 \\
57 \cdot 7 \\
44 \cdot 9\end{array}$ & $\begin{array}{l}<0.01 \\
1.8 \\
<0.01 \\
1.6\end{array}$ & $\begin{array}{l}<0.01 \\
<0.01 \\
<0.01 \\
<0.01\end{array}$ \\
\hline $\begin{array}{l}\text { Basal } \\
\text { After pentagastrin } \\
\text { Insulin control } \\
\text { After insulin } \\
\text { Patient: male } 71 \text { ye }\end{array}$ & $\begin{array}{l}26 \cdot 8 \\
33 \cdot 8 \\
32 \cdot 4 \\
20 \cdot 6 \\
\text { er hepatic ci }\end{array}$ & $\begin{array}{r}3 \cdot 0 \\
2 \cdot 8 \\
3 \cdot 6 \\
4 \cdot 0 \\
\text { hosis }\end{array}$ & $\begin{array}{l}51 \cdot 5 \\
54 \cdot 3 \\
55 \cdot 8 \\
61 \cdot 4\end{array}$ & $\begin{array}{l}5 \cdot 6 \\
5 \cdot 5 \\
6 \cdot 8 \\
8 \cdot 4\end{array}$ & $\begin{array}{l}7 \cdot 1 \\
3 \cdot 5 \\
1 \cdot 8 \\
5 \cdot 5\end{array}$ \\
\hline
\end{tabular}

Results are expressed for each enzyme as a percentage of the total enzyme area calculated afte HPIEC. a high mucus content. There were no significant differences $(\mathrm{p}>0.05)$ in $\mathrm{pH}$ or hydrogen ion concentrations between the different gastric juice collections (table 2), but combined pepsin (including $3 \mathrm{a}, \mathrm{b}, \mathrm{c}$ and 1 ) and gastricsin concentrations were significantly increased by both pentagastrin $(p<0.05)$ and insulin $(p<0.01)$. There was a 2.8 -fold increase in gastricsin concentration after pentagastrin stimulation and a 1.3-fold increase in the combined pepsin 3 concentration. Both the concentrations of gastricsin and pepsin increased two-fold after insulin stimulation compared with the insulin control period.

The mean percentage content of pepsins $3 a, 3 b, 3 c, 1$ in non-stimulated gastric juice was $4 \%, 72 \%, 12 \%$, and $1.4 \%$, respectively, and did not change significantly following gastric stimulation (table 3). An approximate doubling of the percentage of gastricsin (10$20 \%$ ) was observed after both insulin and pentagastrin stimulation compared with the basal value. However, only after insulin stimulation was the gastricsin percentage content significantly ( $p<0.05$ ) increased. Two individual pepsin profiles differed considerably from the eight other patients, with increases in pepsin $3 c$ in one and gastricsin with a significant proportion of pepsin 1 (up to $7 \cdot 1 \%$ ) in the other (table 4 ). In case 1 the relative contribution of pepsins $3 a, b$, and 1 were decreased; in case 2 only pepsin $3 b$ showed a relatively reduced contribution.

\section{Discussion}

A quantitative procedure has been developed for the assay of individual pepsins and gastricsin present in human gastric juice based on their separation by HPIEC. ${ }^{13}$ The within- and between-batch precision for the assay was acceptable for all the enzymes studied. The chromatographic procedure is easy to perform and will allow pepsin profiles to be analysed within one working day-for example, 16 gastric juices collected after a combined pentagastrin insulin secretion study. Porcine pepsin A is readily available commercially and has an $89 \%$ amino acid sequence homology with human pepsin $\mathrm{A}^{15}$ was the most appropriate calibrant for the assay as shown by recoveries of up to $100 \%$ from human gastric juice over the calibration range adopted.
Human pepsin $3 \mathrm{~b}$ generally accounted for $66 \%$ of the total pepsin content in gastric juice, gastricsin $(20 \%)$, and between pepsins $3 a, c$ and 1 (14\%). These findings agree with the data obtained using differential pepstatin inhibition which indicated an $18.0-27.6 \%$ gastricsin content. ${ }^{16}$ Pepstatin, however, does not inhibit pepsin and gastricsin to the same extent, ${ }^{17}$ thus making it unsuitable for quantification of both enzymes. Rocket immunoelectrophoresis ${ }^{10}$ analysis of human gastric juice indicated that the enzyme profile consisted of up to $65 \%$ pepsin and $35 \%$ gastricsin which is slightly higher than our data, probably as a result of cross-reactivities between the pepsin A isoenzymes and gastricsin. In our original technique for pepsin separation by HPIEC ${ }^{18}$ we observed the gastricsin content varied from less than 1 to $32 \%$ total content for one patient after a pentagastrin stimulation test. However, the separation of the enzymes was incomplete and contamination of pepsin subfractions likely. In contrast, the methodology described in this study clearly separates gastricsin from the other pepsin $\mathrm{A}$ isoenzymes and hence cross-reactivity is very unlikely. Previous studies have reported an increased stimulation of gastricsin compared with pepsin by pentagastrin. ${ }^{19}$ Our data support these results and also indicate that pepsin and gastricsin are similarly stimulated by insulin. After pentagastrin and insulin stimulation the gastricsin:pepsin ratios were $1: 3 \cdot 1$ and $1: 2 \cdot 7$, respectively. In basal juice the gastricsin content was lower with a gastricsin:pepsin ratio $(1: 7 \cdot 6)$ and similar to the corresponding serum zymogen ratios $(1: 5 \cdot 8)$ reported in unstimulated samples. ${ }^{20}$

The amount of pepsin output quantified in the basal secretions was in agreement with mean amounts $13.9 \mathrm{mg}$ pepsin $A$ and $4.9 \mathrm{mg}$ of gastricsin obtained by rocket immunoelectrophoresis. ${ }^{10}$ However, a 10 -fold increase in pepsin A and gastricsin in response to pentagastrin was observed in the latter study compared with only a fourfold increase in our study. This difference may be related to a reduced response to stimulation in the patients we studied all of whom had undergone repeated courses of injection sclerotherapy to obliterate their oesophageal varices. Possibly the sclerosant extrasavates through the wall of the oesophagus into the mediastinum resulting in vagal impairment. Alternatively, because all these patients had portal hypertension of varying severity there may have been damage to the chief cells, resulting in a diminished ability to respond to stimulation. However, which if any of these hypotheses is correct requires clarification. Pepsin 1 was present usually at $<0.02 \mathrm{mg} / \mathrm{ml}$ but its percentage content varied ranging from $0-13 \cdot 2 \%$. The value of being able to resolve the individual pepsin $A$ isoenzymes and gastricsin was shown in two patients, one with a sharp increase in $3 c$ (up to $41 \%$ ) and the other gastricsin (up to 34\%). The increased proportions were observed in both basal and stimulated gastric secretion and support the idea that these are individual 
enzymes whose corresponding gene activity might well be genetically predetermined. However, this hypothesis has yet to be established.

Hitherto, because of the problems of accurately measuring pepsin in gastric juice, attempts have been made to quantify and correlate the separate pepsinogens in urine, ${ }^{21}$ or serum $^{22} 23$ with those in gastric mucosa. However, urine assays suffer from problems of differential tubular reabsorption of the isozymogens. $^{24}$ Furthermore, only trace amounts of pepsinogen $C$ (progastricsin) are present. ${ }^{25}$ Consequently, there are discrepancies between gastric mucosal and urinary pepsinogen patterns. ${ }^{21}$ Zwiers et $a l^{22}$ did in fact report a good correlation between serum pepsinogen A mucosal and serum concentrations by immunoblotting after polyacrylamide gel electrophoresis but in general very little information is available on the correlation between mucosal pepsinogen and gastric luminal pepsin concentrations. Recently a bidimensional electrophoretic system has been developed for pepsin quantitation in gastric juice which resolves up to 20 distinct forms and emphasises the complexity of these enzymes. ${ }^{26}$ These pepsin components, however, have not yet been biochemically characterised.

In summary, clinical studies investigating the possible role of pepsins in various gastric pathological states have been hindered by a lack of a suitable assay for quantifying the different human pepsins in gastric juice. This is due to both the nature and availability of gastric juice and the fact that pepsins belong to a multigene family of proteins. This novel, simple, and reliable procedure of quantifying pepsins and gastricsin in gastric juice now described may be of considerable importance in determining the mechanisms involved in the control and secretion of these digestive enzymes in man and experimental animals and hence further our understanding of the pathophysiology of peptic ulcer disease.

1 Etherington DJ, Taylor WH. Nomenclature of the pepsins. Nature (Lond) 1967;216:279-80.

2 Taylor WH. The pepsins of patients with peptic ulcer. Nature (Lond) 1970;227:76-7.

3 Pearson JP, Ward R, Allen A, Roberts NB, Taylor WH. Mucus degradation by pepsin: comparison of mucolytic activity of human pepsin 1 and pepsin 3: implications in peptic ulceration. Gut 1986;27:243-8.
4 Hirschowitz BI. Pepsin in the pathogenesis of peptic ulceration. In: Halter F, Garner A, Tytgat GNJ, eds. Mechanisms of peptic ulcer healing. Proceedings of the 59th Falk symposium held in Freiburg-im-Breisgau, 59th Falk symposium held in Freiburg-im-Breisgau, Germany, October 15-17, 1990. Kluwer

5 Anson ML, Mirsky AE. Estimation of pepsin with haemoglobin. F Gen Physiol 1932;16:59-63.

6 Huang W-Y, Tang J. On the specificity of human gastricsin and pepsin. $\mathcal{F}$ Biol Chem 1969;244:1085-91.

7 Richmond V, Tang J, Wolf S, Trucco RE, Caputto R. Chromatographic isolation of gastricsin, the proteolytic enzyme from gastric juice with $\mathrm{pH}$ optimum 3.2. Biochim Biophys Acta 1958;29:453-4.

8 Foltmann B. Gastric proteinases-structure, function, evolution and mechanism of action. Essays in Biochemistry 1981;17:52-84.

9 Walker V. Aspects of the pathophysiology of the pepsins. MD Thesis University of Liverpool, 1976:82-7.

10 Axelsson CK, Axelsen NH, Szecsi PB, Foltmann B. Determination of pepsin (EC $3 \cdot 4 \cdot 23 \cdot 1$ ) and gastricsin (EC $3 \cdot 4 \cdot 23 \cdot 3$ ) in gastric juice by rocket immunoelecrophoresis. Clin Chim Acta 1983;129:323-31.

11 Walker V, Taylor WH. Cigarette smoking, chronic peptic ulceration, and pepsin 1 secretion. Gut 1979;20:971-6.

12 Hutton DA, Allen A, Pearson JP, Ward R, Venables CW. Separation of pepsins in human gastric juice: analysis of proteolytic and mucolytic activity. Biochem Soc Trans 1986;14:735-6

13 Peek K, Roberts NB, Taylor WH. Improved separation of human pepsins from gastric juice by high-performance ion-exchange chromatography. $₹$ Chromatogr 1989;476: 291-7.

14 Venables CW. An assessment of the value of measuring uncollected gastric secretions during routine secretions in man. Br f Surg 1972;59:473-7.

15 Sogawa K, Fujii-Kuriyama Y, Mizukami Y, Ichihara Y, Takahashi K. Primary structure of the human pepsinogen gene. $\mathcal{F}$ Biol Chem 1983;258:5306-11.

16 Walker V, Taylor WH. Pepsin 5 in gastric juice: Determination and relationship to the alkali-stable peptic activity. Gut 1979;20:977-82.

17 Aoyagi T, Kunimoto S, Morishima H, Takeuchi T, Umezawa $H$. Effect of pepstatin on acid proteases. $\mathcal{F}$ Antibiotics 1971;:24:687-94.

18 Newton CJ, Roberts NB, Taylor WH. Separation of human pepsins in gastric juice by high-performance ionhuman pepsins in gastric juice by high-performance ion391-6.

19 Korbova L, Kohout J, Kasafirek E, Cizkova J. Stomach proteinases separation, specificity, and changes after administration of secretion stimuli. Collection of Czechoslovak Chemical Communications 1977;42: 2577-85.

20 Samloff IM. Pepsinogens I and II: purification from gastric mucosa and radioimmunoassay in serum. Gastroenterology 1982;82:26-33.

21 Pals G, Westerveld BD, Defize J, et al. Discrepancies between gastric mucosal and urinary pepsinogen A patterns and in vitro synthesis and secretion of human terns and in vitro synthesis and secretion

22 Zwiers A, Toonstra C, Pals G, et al. Immunoblot technique to visualise serum pepsinogen A isozymogen patterns. F Clin Pathol 1990;43:871-4.

23 Zwiers A, Crusius B, Pals G, Donker AJM, Meuwissen SGM. Ten Kate RW. Human pepsinogen $A$ isoymogen patterns in serum and gastric mucosa. Gastroenterology 1990;99:1576-80.

24 Ten Dam MAGJ, Zwiers A, Crusius JBA, et al. Tubular reabsorption of pepsinogen isozymogens in man studied by the inhibition of tubular protein reabsorption with dibasic amino acids. Clin Sci 1991;80:161-6.

25 Ten Kate RW, Pals G, Pronk JC, Bank RA, Eriksson AW, Donker AJM, et al. Renal handling of pepsinogens A Donker AJM, et al. Renal handling of
and $C$ in man. Clin Sci 1988;75:649-54.

26 Wnuk W, Jordan M, Loizeau E. Les pepsines ulcerogeniques existent-elles? Characterisation du polymorphisme des pepsines humaines. Schweiz Med Wschr 1991;121:836-8. 